\title{
PENERAPAN SISTEM KOMPUTERISASI HAJI TERPADU (SISKOHAT) TERHADAP PENINGKATAN LAYANAN HAJI PADA KANTOR KEMENTERIAN AGAMA KABUPATEN SUMBAWA
}

\author{
Ardi Suzami ${ }^{1}$, Chairul Hudaya ${ }^{2}$, Rodianto ${ }^{3}$ \\ $1^{*}$ Program Studi Magister Manajemen Inovasi, Sekolah Pascasarjana Universitas Teknologi Sumbawa \\ 2Program Studi Magister Manajemen Inovasi, Sekolah Pascasarjana Universitas Teknologi Sumbawa \\ ${ }^{3}$ Program Studi Teknik Informatika, Fakultas Rekayasa Sistem Universitas Teknologi Sumbawa
}

*Corresponding Author email: 1'suzami29@gmail.com, ${ }^{2}$ c.hudaya@uts.ac.id, ${ }^{3}$ rodianto@uts.ac.id

\begin{tabular}{ll}
\hline & Abstrak \\
\cline { 2 - 3 } Diterima : & Penelitian ini bertujuan untuk mengetahui pengaruh penerapan Sistem Komputerisasi \\
Bulan Juni 2021 & Haji Terpadu (SISKOHAT) terhadap peningkatan layanan haji pada Kantor Kementerian \\
& $\begin{array}{l}\text { Agama Kabupaten Sumbawa. Penelitian ini merupakan penelitian deskriptif kuantitatif. } \\
\text { Jenis data yang digunakan, yaitu data primer didapatkan dari hasil penyebaran kuesioner }\end{array}$ \\
Diterbitkan: & kepada para calon jemaah haji, masyarakat umum, dan petugas/pengelola SISKOHAT \\
Bulan Juli 2021 & Kabupaten Sumbawa. Sampel dalam penelitian adalah 101 responden yang merupakan \\
& calon jemaah haji, 113 responden yang merupakan masyarakat umum, dan 11 responden \\
& yang merupakan petugas/pengelola SISKOHAT. Metode analisis data yang digunakan \\
Keyword: & adalah analisis regresi linear sederhana yang meliputi uji kualitas data, uji asumsi klasik, \\
Penerapan, & dan uji koefisien determinasi. Hasil penelitian menunjukkan bahwa penerapan \\
SISKOHAT, & SISKOHAT berpengaruh positif dan signifikan terhadap layanan haji. Selain itu, \\
Layanan Haji & penerapan SISKOHAT berpengaruh sebesar 82,1\% terhadap peningkatan layanan haji \\
& bagi calon jemaah haji, berpengaruh sebesar 57,3\% bagi masyarakat umum, dan \\
& berpengaruh sebesar 52,6\% bagi petugas/pengelola SISKOHAT. Sisanya sebesar 17,9\% \\
& pada calon jemaah haji, 42,7\% pada masyarakat umum, dan 47,4\% pada \\
& petugas/pengelola SISKOHAT dipengaruhi oleh variabel lain yang tidak dibahas dalam \\
& penelitian ini..
\end{tabular}

\section{PENDAHULUAN}

Penyelenggaraan ibadah haji sebagai tugas nasional merupakan tanggungjawab Pemerintah sebagaimana diamanatkan dalam Undang-Undang Nomor 8 Tahun 2019 tentang Penyelenggaraan Ibadah Haji dan Umrah. Penyelenggaraan ibadah haji oleh Pemerintah bertujuan untuk memberikan pembinaan, pelayanan, dan pelindungan bagi jemaah haji sehingga dapat menunaikan ibadahnya sesuai dengan ketentuan syariat dan mewujudkan kemandirian dan ketahanan dalam penyelenggaraan ibadah haji.

Dalam upaya meningkatkan pelayanan penyelenggaraan ibadah haji, Kementerian Agama membangun sistem teknologi informasi haji secara terintegrasi yang lebih dikenal dengan Sistem Informasi dan Komputerisasi Haji Terpadu (SISKOHAT). Fungsi utama sistem ini diterapkan adalah untuk melayani pendaftaran haji yang dapat dimonitor dan dikendalikan secara terpusat, on-line dan real-time antara Bank Penerima Setoran Biaya Penyelenggaraan Ibadah Haji (BPS BPIH), Kantor Wilayah Kementerian Agama di 33 Provinsi dan Kabupaten dengan Host Pusat Komputer untuk penyimpanan seluruh database calon jemaah haji di Kementerian Agama Pusat.
Sistem Informasi dan Komputerisasi Haji Terpadu (SISKOHAT) pertama kali diterapkan di Indonesia pada tahun 2010 dengan penerapan SISKOHAT Gen-1, termasuk salah satu diantaranya adalah Kantor Kementerian Agama Kabupaten Sumbawa yang menerapkannya pada bulan Nopember 2010. Penerapan sistem ini dilakukan untuk mengatasi permasalahan yang ada pada pelayanan informasi dan pengolahan data jemaah haji baik dokumentasi, pengarsipan sampai pada pengurusan keuangan yang masih dilakukan secara manual sehingga sulit dikontrol secara cepat. Dalam penerapannya, SISKOHAT Gen-1 masih belum dapat memberikan layanan maksimal kepada calon jemaah haji, karena proses layanan haji masih membutuhkan waktu yang cukup lama. Pada tahun 2014 dilakukan penyempurnaan dan pengembangan sistem dengan diluncurkannya SISKOHAT Gen-2 yang proses layanannya lebih cepat. Pada SISKOHAT Gen-1 proses pendaftaran masih menggunakan 4 (empat) tahap, sedangkan pada SISKOHAT Gen-2 ini proses yang dilakukan menjadi 2 (dua) tahap. Kemudian pada tahun 2016, SISKOHAT Gen-2 disempurnakan lagi dengan diluncurkannya SISKOHAT Gen-2 Versi 3, dimana pada pembaruan sistem ini ditambah dengan penerapan sistem biometric. Pada tahun 2021, seluruh cetakan dokumen calon jemaah haji harus 
di-upload ke dalam SISKOHAT Gen-2 Versi 3 agar data calon jemaah haji dapat terjaga keamanannya dan dapat terintegrasi secara menyeluruh ke dalam sistem.

Upaya untuk meningkatkan pelayanan haji menjadi sebuah keniscayaan yang dilakukan oleh Kantor Kementerian Agama Kabupaten Sumbawa. Evaluasi terhadap hasil penyelenggaraan haji dari tahun ke tahun yang kemudian ditindaklanjuti dengan perbaikan pola layanan untuk mengatasi kekurangan-kekurangan yang terjadi senantiasa harus terus dilakukan. Kantor Kementerian Agama Kabupaten Sumbawa sebagai penyelenggara dan pemberi layanan haji di wilayah Kabupaten Sumbawa adalah lembaga yang berperan penuh dalam melakukan pendaftaran jemaah haji dengan menggunakan Sistem Informasi dan Komputerisasi Haji Terpadu (SISKOHAT) sebagai pelayanannya.

Untuk meningkatkan layanan bagi calon jemaah haji diperlukan inovasi layanan yang dilakukan oleh Kantor Kementerian Agama Kabupaten Sumbawa terutama untuk mendekatkan pelayanan pendaftaran dan informasi haji bagi masyarakat dari wilayah Kecamatan yang sulit terjangkau diantaranya adalah Kecamatan Batu Lanteh, Kecamatan Ropang, Kecamatan Lantung, dan sebagian Kecamatan Lenangguar.

\section{LANDASAN TEORI}

\section{Penerapan (Implementasi)}

Menurut kamus besar bahasa Indonesia (KBBI), pengertian penerapan ialah proses, cara, dan perbuatan menerapkan. Kata penerapan berasal dari kata terap yang berarti menjalankan atau melakukan suatu kegiatan, kemudian menjadi berarti. Suatu proses, cara, atau perbuatan menjalankan, atau melakukan sesuatu baik yang abstrak maupun yang konkrit. Penerapan merupakan sebuah tindakan yang dilakukan baik secara individu maupun kelompok dengan maksud untuk mencapai suatu tujuan yang telah dirumuskan.

Ripley dan Franklin (dalam Winarno, 2016: 134) berpendapat bahwa implementasi adalah apa yang terjadi setelah undang-undang ditetapkan yang memberikan otoritas program, kebijakan, keuntungan (benefit) atau suatu jenis keluaran yang nyata (tangible output). Istilah implementasi menunjuk pada sejumlah kegiatan yang mengikuti pernyataan maksud tentang tujuan-tujuan program dan hasil-hasil yang diinginkan oleh para pejabat pemerintah, dengan maksud untuk membuat program berjalan. Lebih jauh menurut, Ripley dan dan Franklin implementasi mencakup banyak macam kegiatan. Pertama, badan-badan pelaksana yang ditugasi undang-undang dengan tanggungjawab menjalankan program harus mendapatkan sumber-sumber yang dibutuhkan agar implementasi berjalan lancar. Kedua, badan-badan pelaksana mengembangkan bahasa anggaran dasar menjadi arahan-arahan konkrit, regulasi, serta rencana-rencana dan desain program. Ketiga, badanbadan pelaksana harus mengorganisasikan kegiatankegiatan dengan menciptakan unit-unit birokrasi dan rutinitas untuk mengatasi beban kerja.

Sementara itu, Grindle (dalam Winarno, 2016: 135) juga memberikan pandangannya tentang implementasi dengan mengatakan bahwa secara umum, tugas implementasi adalah membentuk suatu kaitan (linkage) yang memudahkan tujuan-tujuan kebijakan bisa direalisasikan sebagai dampak dari suatu kegiatan pemerintah. Oleh karena itu, tugas implementasi mencakup terbentuknya "a policy delivery sistem" di mana sarana-sarana tertentu dirancang dan dijalankan dengan harapan sampai pada tujuan-tujuan yang diinginkan.

\section{Pelayanan Publik}

Berdasarkan Undang-Undang Republik Indonesia Nomor 25 Tahun 2009 pasal satu (1) Tentang Pelayanan Publik memberikan defenisi pelayanan publik sebagai berikut: "Pelayanan Publik adalah kegiatan atau rangkaian kegiatan dalam rangka pemenuhan kebutuhan pelayanan sesuai dengan peraturan perundang-undangan bagi setiap warga Negara dan penduduk atas barang, jasa, dan/atau pelayanan administrasi yang disediakan oleh penyelenggara pelayanan publik"

Menurut Keputusan Menteri Pemberdayaan Aparatur Negara Nomor 25 Tahun 2004: "pelayanan publik adalah segala kegiatan pelayanan yang dilaksanakan oleh penyelenggara pelayanan publik sebagai upaya pemenuhan kebutuhan penerima pelayanan, maupun dalam rangka pelaksanaan ketentuan perundangundangan".

Menurut Hayat (2017 : 22) "pelayanan publik merupakan melayani secara keseluruhan aspek pelayanan dasar yang dibutuhkan oleh masyarakat untuk dipenuhi sesuai dengan ketentuannya" Mukaron dan Laksana, (2016:41) mengatakan bahwa : "Pelayanan Publik adalah pemberian layananan (melayani) keperluan orang atau masyarakat yang mempunyai kepentingan pada organisasi sesuai dengan aturan pokok dan tata cara yang telah ditetapkan".

Thijs, Hammerschmid, dan Palaric (2017) mengklasifikasikan konsep pelayanan publik sebagai berikut:

1. Pelayanan publik yang efisien dari perspektif pemberi layanan, pemberi harus mengusahakan agar harga pelayanan murah dan tidak terjadi pemborosan sumber daya publik. Demikian juga dari perspektif pengguna layanan, mereka menghendaki pelayanan publik dapat dicapai dengan biaya yang murah, waktu singkat, dan tidak banyak membuang energi.

2. Pelayanan publik yang responsif adalah kemampuan organisasi untuk mengidentifikasi kebutuhan masyarakat menyusun prioritas 
kebutuhan, dan mengembangkannya ke dalam berbagai program pelayanan.

3. Pelayanan publik yang non-partisan adalah sistem pelayanan yang memperlakukan semua pengguna layanan secara adil tanpa membedabedakan berdasarkan status sosial ekonomi, kesukuan, etnik, agama, kepartaian, dan sebagainya.

\section{Pelayanan Publik}

Strategi inovasi dalam pemerintahan juga dijelaskan dalam buku Innovative Government oleh Sangkala (2013) yaitu :

a. Layanan terintegrasi

Dimana sektor publik menawarkan peningkatan sejumlah layanan, warga memiliki harapan yang tidak sederhana dimana warga meminta layanan yang disediakan disertai dengan kenyamanan.

b. Desentralisasi

Pemberian dan monitoring layanan lebih dekat dengan masyarakat dan biasanya membentuk kepastian tehadap tingkat permintaan yang tinggi sehingga meningkatkan kepuasan masyarakat atau pelaku bisnis.

c. Pemanfaatan kerjasama

Bermakna sebagai pemerintahan yang inovatif untuk memenuhi peningkatan pemenuhan agar lebih efisien dalam pemberian layanan publik, lebih kolaboratif antar organisasi dan juga terjadi kerjasama antara publik dan swasta.

d. Pelibatan warga Negara

Kewenangan pemerintah yang Inovatif harus merealisasikan peran peran pentingnya dengan mendorong peran warga untuk berpartisipasi dalam mendorong perubahan.

e. Pemanfaatan teknologi komunikasi dan informasi.

\section{Sistem Informasi dan Komputerisasi Haji Terpadu (SISKOHAT)}

Penyelenggaraan ibadah haji di Indonesia dari tahun ke tahun mengalami peningkatan jumlah pendaftar yang sangat signifikan, sehingga menuntut pemerintah untuk mengupayakan pelayanan terbaik dan berkualitas setiap tahunnya. Dalam meningkatkan pelayanan penyelenggaraan ibadah haji, Kementerian Agama menumbuh kembangkan sistem pendataan palayanan haji melalui pemanfaatan pelayanan teknologi informasi dan komunikasi yang dilakukan di Tanah Air dan Arab Saudi yang disebut Sistem Informasi dan Komputerisasi Haji Terpadu (SISKOHAT).

Pembangunan SISKOHAT dirancang untuk meningkatkan kualitas pelayanan ibadah haji secara signifikan. Dengan adanya sistem yang terintegrasi dan terpusat memperkecil kemungkinan kesalahan dalam pengisian data atau melakukan kecurangan dalam penetapan nomor porsi calon untuk jamaah haji. Siskohat juga membantu mempercepat proses pembukaan rekening awal pada bank BPS BPIH yang telah ditetapkan hingga mendapatkan nomor porsi haji.

SISKOHAT adalah sistem untuk mengolah seluruh data perhajian di Indonesia yang sudah berbasiskan teknologi informasi, yang bertugas mengatur pendaftaran, database dokumen haji, akuntansi BPIH, database transportasi haji, database penempatan pemondokan jemaah, informasi publik, sistem informasi kesehatan haji, dan database petugas haji (Mutmainnah, 2011:72). Penyelenggaraan ibadah haji tidak saja terkait dengan serangkaian kegiatan ritual, tetapi juga terkait dengan serangkaian kegiatan lain seperti pendaftaran, pembinaan haji, pelayanan pemondokan, katering, transportasi darat dan udara, kesehatan, dan perlindungan jemaah baik yang dilakukan didalam tanah air maupun yang dilakukan di Arab Saudi (Fahham, 2015:202).

Tujuan dibentuknya SISKOHAT adalah: (1) Agar jemaah calon haji dan masyarakat mudah mengakses baik langsung maupun tidak langsung semua data informasi tentang haji. (2) Untuk meningkatkan wawasan dan pengetahuan jemaah calon haji sehingga tercipta jemaah calon haji yang berwawasan dan mandiri. (3) Untuk memberikan pelayanan informasi kepada masyarakat secara profesional sehingga informasi dapat disampaikan secara cepat, tepat dan akurat (Novitasari, 2017:16).

\section{METODE PENELITIAN}

Penelitian ini dilaksanakan di Kantor Kementerian Agama Kabupaten Sumbawa yang beralamat di jalan Duriannomor 72 Sumbawa Besar NTB pada tahun 2021. Populasi dalam penelitian ini berjumlah 727 orang yaitu calon jemaah haji tahun 2020 pada Kantor Kementerian Agama Kabupaten Sumbawa. Sedangkan Teknik pengambilan sampel yang digunakan dalam penelitian ini menggunakan pendekatan slovin sehingga pengambilan sampel dapat dilakukan dengan tepat dan dapat mewakili populasi, sehingga yang menjadi sampel pada penelitian ini adalah 101 calon jemaah haji tahun 2020 pada Kantor Kementerian Agama Kabupaten Sumbawa. Selain itu, 113 masyarakat umum dan 11 petugas/pengelola SISKOHAT juga diajdikan sebagai sampel untuk memperkuat hasil analisis. Jenis data yang digunakan pada penelitian ini adalah pendekatan kuantitatif dan deskriptif. Teknik pengumpulan data yang digunakan adalah wawancara, kuesioner, dokumentasi, studi pustaka dan observasi. Sedangkan teknik analisis data yang digunakan adalah menggunakan uji validitas, uji reliabilitas, uji normalitas, uji regresi linear sederhana, uji hipotesis dan uji koefisien determinasi.

\section{HASIL DAN PEMBAHASAN}

Penerapan Sistem Komputerisasi Haji Terpadu 
Kementerian Agama sebagai sub sistem pemerintahan Republik Indonesia mempunyai tugas melaksanakan sebagian tugas pemerintah di bidang agama. Dalam melaksanakan tugasnya tersebut, Kementerian Agama Kabupaten Sumbawa lebih banyak menitikberatkan pada pelayanan terhadap masyarakat di bidang agama. Seiring dengan perkembangan tuntutan pelayanan pada masyarakat yang semakin kompleks, perlu terus ditingkatkan kualitas kinerja pelayanan kepada masyarakat. Baik buruknya pelayanan yang diberikan oleh Kementerian Agama Kabupaten Sumbawa akan menentukan citra Kementerian Agama di masyarakat, karena dengan semakin baiknya pelayanan, maka kepuasan dan kepercayaan akan dapat diwujudkan.

Dalam hal pendaftaran ibadah haji melalui SISKOHAT Gen-2 atau Sistem Informasi dan Komputerisasi Haji Terpadu yang dioperasikan secara bersarnbung (online) dengan Bank Penerima Setoran Biaya Penyelenggaraan Ibadah Haji (BPS $\mathrm{BPIH}$ ), sehingga bisa memberikan pelayanan yang prima serta kepastian kepada pendaftar calon jemaah haji bahwa yang bersangkutan sudah sah terdaftar sebagai calon haji dan dibuktikan oleh bukti setoran BPIH yang dicetak secara otomatis oleh Bank Penerima Setoran (BPS), pada saat itu calon jemaah haji memperoleh nomor validasi dari SISKOHAT Gen-2. Hal ini dimaksudkan agar pelayanan pendataan dan informasi dapat dilakukan dengan cepat, tepat, dan akurat, baik untuk kepentingan manajemen, jemaah haji maupun masyarakat.

Sistem Informasi dan Komputerisasi Haji Terpadu (SISKOHAT) kini menjadi "jantung" bagi pelayanan jemaah haji, karena seluruh proses pengolahan data untuk kepentingan baik pendaftaran, pembatalan dan pelunasan bahkan pembuatan paspor, penerbangan (pemberangkatan dan pemulangan), perbankan dan biodata calon jemaah haji mengacu pada sistem komputer terpadu tersebut.

Kementerian Agama Republik Indonesia membuat sistem pendaftaran calon jemaah haji menjadi lebih mutakhir. Aplikasinya berbasis web. Sehingga SISKOHAT Gen-2 memungkinkan Direktorat Jenderal Penyelenggaraan Haji dan Umrah terhubung dengan Bank Penerima Setoran Biaya Penyelenggaraan Ibadah Haji (BPS BPIH) dan Kantor Kementerian Agama Kabupaten/Kota secara online dan realtime.

Sistem teknologi informasi harus dioptimalkan, sistem online sudah harus real time dengan pemanfaatan "grand design" yang sudah terbangun dan juga akurasinya harus tepat. Pengguna dalam melaksanakan pelayanan juga harus disertai dengan kemampuan manajemen waktu layanan dengan menggunakan standar operasional dan prosedur yang jelas dan terarah.
Berdasarkan data yang diperoleh dari informan bahwa prosedur pendaftaran haji pada Seksi Penyelenggaraan Haji dan Umrah Kantor Kementerian Agama Kabupaten Sumbawa sebagai berikut :

1. Langkah pertama Calon Jemaah Haji ke Bank Penerima Setoran BPIH untuk melakukan:

a. Memebuka tabungan haji minimal Rp.25.000.000,-

b. Mencetak Bukti Setoran Awal BPIH atau Nomor Validasi.

Persyaratan:

- Berusia minimal 18 Tahun atau sudah menikah;

- Foto copy KTP;

- Foto copy Kartu Keluarga;

- Materai 10.000 sebanyak 2 lembar;

- Phas Photo haji berwarnah latar belakang putih dengan tampak wajah $80 \%$ ukuran $3 \mathrm{x}$ $4=6$ lembar;

- Uang Setoran Awal BPIH sebesar Rp.25.000.000,-

2. Langkah kedua Setelah proses di bank selesai, Calon Jemaah Haji menuju ke Kantor Kementerian Agama Kabupaten Sumbawa paling lama 5 hari setelah nomor validasi diperoleh dari Bank, untuk melakukan:

a. Perekaman biometric dan foto online pada aplikasi SISKOHAT;

b. Mencetak Surat Pendaftaran Pergi Haji (SPPH) atau Nomor Porsi;

Persyaratan :

- Tanda Bukti Setoran Awal dari bank, lembar 2, 3, dan 4;

- Foto copy KTP sebanyak 5 lembar;

- Foto copy Kartu Keluarga sebanyak 2 lembar;

- Foto copy salah satu dari Buku Kutipan Akta Nikah, Ijazah, Akta Kelahiran (salah satu harus ada) sebayak 2 lembar.

- Phas photo haji berwarnah latar belakang putih dengan tampak wajah $80 \%$ ukuran $3 \mathrm{x}$ $4=10$ lembar dan 4 × $6=5$ lembar.

- Keterangan Dokter memuat golongan darah, tinggi badan dan berat badan.

- Foto copy Buku Tabungan Haji sebanyak 1 lembar;

- Foto copy paspor bagi yang telah memiliki;

3. Nama-nama Bank Penerima Setoran Haji di Kabupaten Sumbawa:

- Bank Syariah Indonesia;

- Bank Kantor Kementerian Agama Kabupaten Sumbawa;

- Bank Muamalat Indonesia;

\section{Data Responden}

Berdasarkan hasil penyebaran kuesioner yang dilakukan melalui layanan google form diperoleh 225 responden yang terdiri atas calon jemaah haji yang sudah mendaftar sebanyak 101 responden, masyarakat umum yang belum 
mendaftar sebanyak 113 responden, dan pengelola SISKOHAT sebanyak 11 responden.

\section{Uji Hipotesis}

Uji hipotesis menggunakan uji $t$, uji $t$ digunakan untuk mrngetahui apakah variabel independen berpengaruh secara signifikan atau tidak terhadap variabel dependen (Sugiyono, 2014:261). Untuk melihat pengaruh variabel independen terhadap dependen, uji $\mathrm{t}$ dilakukan dengan membandingkan nilai $t_{\text {hitung }}$ dengan $t_{\text {tabel }}$. Kriteria pengujiannya, yaitu: jika nilai $\mathrm{t}_{\text {hitung }}<\mathrm{t}_{\text {tabel }}$ maka hipotesis ditolak. Jika nilai $t_{\text {hitung }}>t_{\text {tabel }}$ maka hipotesis diterima.

Untuk pengujian hipotesis dalam penelitian ini dapat dijabarkan dimana :

- nilai $t_{\text {hitung }}$ sebesar 21,334 pada taraf signifikan $5 \%$ dan $\mathrm{df}=\mathrm{n}-\mathrm{k}-1=101-2-1=98$, sehingga di dapat nilai $t_{\text {tabel }}$ sebesar 1,984. Adapun hasil dari interprestasi diketahui nilai $t_{\text {hitung }} 21,334>t_{\text {tabel }}$ 1,984 .

- nilai $t_{\text {hitung }}$ sebesar 12,212 pada taraf signifikan $5 \%$ dan df = n-k-1 = 113-2-1 = 110, sehingga di dapat nilai $t_{\text {tabel }}$ sebesar 1,982. Adapun hasil dari interprestasi diketahui nilai $t_{\text {hitung }} 12,212>\mathrm{t}_{\text {tabel }}$ 1,982 .

- nilai thitung sebesar 3,159 pada taraf signifikan 5\% dan $\mathrm{df}=\mathrm{n}-\mathrm{k}-1=11-2-1=8$, sehingga di dapat nilai $t_{\text {tabel }}$ sebesar 1,833. Adapun hasil dari interprestasi diketahui nilai $t_{\text {hitung }} 3,159>\mathrm{t}_{\text {tabel }}$ 1,833 .

Sehingga dapat dikatakan bahwa hipotesis diterima yang berarti terdapat pengaruh antara variabel penerapan SISKOHAT terhadap peningkatan layanan haji pada Kantor Kementerian Agama Kabupaten Sumbawa.

\section{Uji Koefisien Determinasi}

Uji koefisien determinasi (R2) bertujuan untuk mengukur komponen model dalam menerangkan variasi variabel terikat.

\section{Tabel 1 Hasil Koefisien Determinasi Calon Haji} Model Summary ${ }^{b}$

\begin{tabular}{|c|c|c|c|}
\hline $\mathbf{R}$ & |uare & $\begin{array}{l}\text { Adjusted } \\
\text { e R Square t }\end{array}$ & $\begin{array}{l}\text { Std. Error of } \\
\text { he Estimate }\end{array}$ \\
\hline 0,9 & 0,821 & 0,820 & 1,386 \\
\hline
\end{tabular}

a. Predictors: (Constant), SISKOHAT

b. Dependent Variable: Layanan_Haji

Sumber: Data primer yang diolah (2021).

Berdasarkan tabel 1 dapat dijelaskan bahwa besarnya nilai korelasi (R) yaitu sebesar 0,906 yang artinya terdapat hubungan yang sangat kuat antara variable penerapan Sistem Komputerisasi Haji Terpadu (SISKOHAT) dengan peningkatan layanan haji. Sedangkan nilai Adjusted $\mathrm{R}$ Square sebesar 0,821 atau sama dengan $82,1 \%$, hal ini menunjukkan bahwa besar persentase pengaruh variabel penerapan Sistem Komputerisasi Haji Terpadu (SISKOHAT) dengan peningkatan layanan haji adalah sebesar $82,1 \%$, sedangkan sisanya sebesar $17,9 \%$ dipengaruhi oleh variabel lain yang tidak diteliti dalam penelitian ini.

Tabel 2 Hasil Koefisien Determinasi Masyarakat Umum

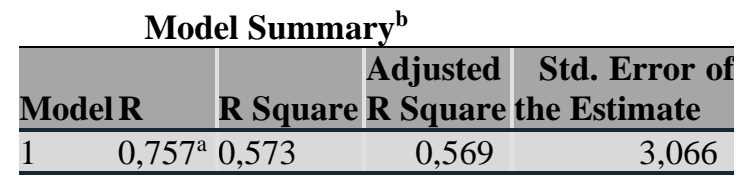

a. Predictors: (Constant), SISKOHAT

b. Dependent Variable: Layanan_Haji

Sumber: Data primer yang diolah (2021).

Berdasarkan tabel 2 dapat dijelaskan bahwa besarnya nilai korelasi (R) yaitu sebesar 0,757 yang artinya terdapat hubungan yang sangat kuat antara variable penerapan Sistem Komputerisasi Haji Terpadu (SISKOHAT) dengan peningkatan layanan haji. Sedangkan nilai Adjusted R Square sebesar 0,573 atau sama dengan 57,3\%, hal ini menunjukkan bahwa besar persentase pengaruh variabel penerapan Sistem Komputerisasi Haji Terpadu (SISKOHAT) dengan peningkatan layanan haji adalah sebesar 57,3\%, sedangkan sisanya sebesar $42,7 \%$ dipengaruhi oleh variabel lain yang tidak diteliti dalam penelitian ini.

Tabel 3 Hasil Koefisien Determinasi Petugas/Pengelola SISKOHAT

Model Summary ${ }^{b}$

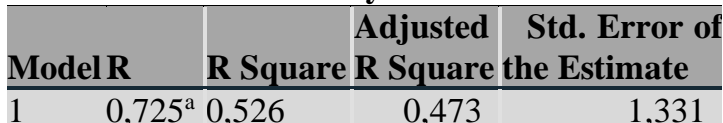

a. Predictors: (Constant), SISKOHAT

b. Dependent Variable: Layanan_Haji

Sumber: Data primer yang diolah (2021).

Berdasarkan tabel 3 dapat dijelaskan bahwa besarnya nilai korelasi (R) yaitu sebesar 0,725 yang artinya terdapat hubungan yang sangat kuat antara variabel penerapan Sistem Komputerisasi Haji Terpadu (SISKOHAT) dengan peningkatan layanan haji. Sedangkan nilai Adjusted R Square sebesar 0,526 atau sama dengan 52,6\%, hal ini menunjukkan bahwa besar persentase pengaruh variabel penerapan Sistem Komputerisasi Haji Terpadu (SISKOHAT) dengan peningkatan layanan haji adalah sebesar 52,6\%, sedangkan sisanya sebesar $47,4 \%$ dipengaruhi oleh variabel lain yang tidak diteliti dalam penelitian ini.

Penelitian penerapan SISKOHAT terhadap peningkatan layanan haji pada Kantor Kementerian Agama Kabupaten Sumbawa dibagi menjadi tiga, yaitu pengaruh variabel penerapan SISKOHAT terhadap layanan haji bagi calon jemaah haji, pengaruh variabel penerapan SISKOHAT terhadap layanan haji bagi masyarakat umum, dan pengaruh variabel penerapan SISKOHAT terhadap layanan haji bagi petugas/pengelola SISKOHAT. 
Penjabaran dari tiga hipotesa tersebut dapat diuraikan sebagai berikut:

Hasil penelitian yang dilakukan, bahwa koefisien beta unstandardized variabel penerapan SISKOHAT sebesar 0,749 dan (sig) t sebesar 0,000 untuk calon jemaah haji, 0,694 dan (sig) t sebesar 0,000 untuk masyarakat umum, dan 0,628 dan (sig) $\mathrm{t}$ sebesar 0,012 untuk petugas/pengelola SISKOHAT. Berdasarkan hasil analisis tersebut, menunjukkan bahwa variabel penerapan SISKOHAT berpengaruh secara positif dan signifikan terhadap variabel layanan haji. Oleh karena itu, semakin baik penerapan SISKOHAT yang dilakukan oleh Kantor Kementerian Agama Kabupaten Sumbawa sebagai penyedia layanan, maka semakin baik pula layanan haji yang diterima oleh calon jemaah haji dan masyarakat umum. Penerapan SISKOHAT juga berpengaruh positif bagi petugas/pengelola SISKOHAT dalam memberikan pelayanan.

Hal tersebut didukung dengan distribusi jawaban responden yang menyatakan bahwa dengan penerapan SISKOHAT, proses layanan haji menjadi mudah dengan persentase jawaban setuju sebesar $50,5 \%$ dan persentase sangat setuju sebesar $43,6 \%$. Selain itu, responden yang menyatakan bahwa dengan penerapan SISKOHAT, proses layanan haji menjadi cepat dengan persentase jawaban setuju sebesar $45,5 \%$ dan dengan persentase jawaban sangat setuju sebesar $45,5 \%$. Selanjutnya, responden yang menyatakan dengan menggunakan SISKOHAT memperoleh layanan haji yang sangat baik dengan persentase jawaban setuju sebesar $25,7 \%$ dan dengan persentase jawaban sangat setuju sebesar 64,4\%. Masyarakat telah mendapatkan informasi layanan haji menggunakan SISKOHAT dengan persentase jawaban setuju sebesar 30,1\% dan persentase sangat setuju sebesar $30,1 \%$. Selain itu, penerapan SISKOHAT agar dapat disosialisasikan lebih masif agar dapat meningkatan pemahaman masyarakat luas terutama masyarakat yang ingin mendapatkan porsi sebagai calon jamaah haji. Responden yang menyatakan bahwa perlu mendapatkan sosialisasi mengenai layanan haji menggunakan SISKOHAT dengan persentase jawaban setuju sebesar $24,8 \%$ dan dengan persentase jawaban sangat setuju sebesar $63,7 \%$. Selanjutnya, responden yang menyatakan perlu mendapatkan layanan haji yang lebih dekat dengan persentase jawaban setuju sebesar 12,4\% dan dengan persentase jawaban sangat setuju sebesar $79,6 \%$. Penerapan SISKOHAT, proses layanan haji menjadi mudah dengan persentase jawaban setuju sebesar $54,5 \%$ dan persentase sangat setuju sebesar $45,5 \%$. Selain itu, responden yang menyatakan bahwa penerapan SISKOHAT, proses layanan haji menjadi cepat dengan persentase jawaban setuju sebesar $18,2 \%$ dan dengan persentase jawaban sangat setuju sebesar $54,5 \%$. Selanjutnya, responden yang menyatakan bahwa dapat memberikan layanan haji yang lebih baik dengan menggunakan SISKOHAT dengan persentase jawaban setuju sebesar 18,2\% dan dengan persentase jawaban sangat setuju sebesar $63,6 \%$.

Beberapa faktor yang mempengaruhi penerapan SISKOHAT terhadap peningkatan layanan haji, seperti kemudahan layanan yang didapatkan oleh calon jemaah haji pada Kantor Kementerian Agama Kabupaten Sumbawa dengan menggunakan SISKOHAT. Hal lain yang mendukung peningkatan layanan haji, yaitu dengan menggunakan SISKOHAT, Kantor Kementerian Agama Kabupaten Sumbawa dapat memberikan layanan yang lebih cepat bagi calon jemaah haji. Penelitian ini didukung oleh hasil penelitian sebelumnya yang dilakukan oleh Herni Yuliani, Ahmad Sarbini, \& Herman dengan penelitiannya yang berjudul Implementasi Sistem Komputerisasi Haji Terpadu (Siskohat) dalam Transparansi Informasi kepada Calon Jemaah Haji. Penelitian tersebut diterbitkan pada tahun 2016 dengan hasil keberadaan Sistem Komputerisasi Haji Terpadu (SISKOHAT) sebagai pusat informasi sangatlah membantu, baik Pemerintah, Jemaah Haji serta para pengelola, ditengah upaya peningkatan pelayanan haji yang berkualitas. Selain itu, penelitian lain yang dilakukan oleh Zahrotun, M. Mudhofi, Dedy Susanto pada tahun 2017 dengan judul Efektivitas Sistem Informasi dan Komputerisasi Haji Terpadu (SISKOHAT) Dalam Penyelenggaraan Ibadah Haji. Hasil penelitian menunjukkan bahwa SISKOHAT dalam penyelenggaraan ibadah haji di Kantor Wilayah Kementerian Agama Provinsi Jawa Tengah telah berlangsung secara efektif dan tidak lepas dari faktor pendukung serta faktor penghambat. Penelitian lain yang mendukung hasil penelitian, yaitu penelitian yang dilakukan oleh Afriani, Saiful Bahri, Thanthawi Ishak yang diterbitkan pada tahun 2020 dengan judul Peran Kantor Kementerian Agama Kabupaten Aceh Utara dalam Melaksanakan Sistem Informasi dan Komputerisasi Haji Terpadu. Hasil penelitian tersebut menunjukkan bahwa SISKOHAT berperan dalam pelayanan haji yang dilakukan oleh Kantor Kementerian Agama Kabupaten Aceh Utara.

Untuk dapat lebih meningkatkan layanan haji yang diberikan oleh Kantor Kementerian Agama, diperlukan suatu inovasi layanan karena masih ada pengaruh variabel lain yang mempengaruhi peningkatan layanan haji sebesar $17,9 \%$ bagi calon jemaah haji, $42,7 \%$ bagi masyarakat umum, dan $47,4 \%$ bagi petugas/pengelola.

Salah satu inovasi layanan yang dapat diterapkan adalah Layanan SISKOHAT Billing (Mobil Keliling). Layanan ini untuk lebih mendekatkan pelayanan, memberikan kemudahan dan kenyamanan layanan bagi masyarakat, khususnya di wilayah kecamatan yang sulit terjangkau diantaranya adalah Kecamatan Batu 
Lanteh, Kecamatan Ropang, Kecamatan Lantung, dan sebagian Kecamatan Lenangguar. Layanan berbentuk satu unit mobil operasional yang direhab menjadi mobil yang dapat memberikan pelayanan SISKOHAT. Layanan ini merupakan kerjasama antara Kemenag Kabupaten Sumbawa dengan pihak-pihak terkait seperti perbankan, catatan sipil, dan puskesmas. Karena dalam pendaftaran haji terkait dengan pihak-pihak tersebut. Layanan SISKOHAT Billing ini dibuat jadwal kunjungan ke kecamatan-kecamatan untuk memberikan layanan pendaftaran haji, layanan pembatalan haji, rekomendasi umrah, dan informasi haji. Berdasarkan hasil jawaban responden sangat setuju sebesar 79,6\% dengan Layanan SISKOHAT Billing (Mobil Keliling).

\section{PENUTUP}

\section{Kesimpulan}

Berdasarkan hasil dan pembahasan penelitian yang telah dikemukakan maka dapat disimpulkan bahwa penerapan Sistem Komputerisasi Haji Terpadu (SISKOHAT) mempengaruhi peningkatan layanan haji secara signifikan pada Kantor Kementerian Agama Kabupaten Sumbawa dengan persentase pengaruh sebesar $82,1 \%$ bagi calon jemaah haji, 57,3\% bagi masyarakat umum, dan $52,6 \%$ bagi petugas/pengelola. Namun, layanan tersebut dapat ditingkatan karena masih ada pengaruh variabel lain yang mempengaruhi peningkatan layanan haji sebesar $17,9 \%$ bagi calon jemaah haji, $42,7 \%$ bagi masyarakat umum, dan $47,4 \%$ bagi petugas/pengelola.

Penulis menyarankan agar Kantor

Kementerian Agama Kabupaten Sumbawa membuat inovasi layanan. Salah satu inovasi layanan yang dapat diterapkan adalah Layanan SISKOHAT Billing (Mobil Keliling). Layanan ini dapat lebih mendekatkan pelayanan kepada masyarakat. Berdasarkan hasil jawaban responden calon jemaah haji sebesar $79,6 \%$ sangat setuju dengan Layanan SISKOHAT Billing (Mobil Keliling). Selain itu, penerapan SISKOHAT agar dapat disosialisasikan lebih masif agar dapat meningkatan pemahaman masyarakat luas terutama masyarakat yang ingin mendapatkan porsi sebagai calon jamaah haji. Kemudian penulis juga menyarankan agar dapat dilakukan penelitian lanjutan menggunakan variabel lain.

\section{REFERENSI}

Bungin. Prof. Dr. H.M. B. 2017. Metodologi Penelitian Kuantitatif (Komunikasi, Ekonomi, dan Kebijakan Publik Serta ilmu Sosial). Jakarta: Kencana.

Creswel. J. W. 2014. Research Design Pendekatan Kualitatif, Kuantitatif, dan Mixed.
Terjemahan Achmad Fawaid. Yogyakarta: Pustaka Pelajar.

Hayat. 2017. Manajemen Pelayanan Publik. Depok: PT Raja Grafindo Persada.

Kristanto, A. 2008. Perancangan Sistem Informasi dan Aplikasinya. Yogyakarta: Gava Media.

Peraturan Menteri Agama RI. 2019. Peraturan Menteri Agama Republik Indonesia Nomor 6 Tahun 2019 tentang Perubahan Atas Peraturan Menteri Agama Nomor 13 Tahun 2018 tentang Penyelenggaraan Ibadah Haji Reguler.

Peraturan Menteri Pendayagunaan Aparatur Negara dan Reformasi Birokrasi RI. 2014. Peraturan Menteri Pendayagunaan Aparatur Negara dan Reformasi Birokrasi Republik Indonesia Nomor 30 Tahun 2014 tentang Pedoman Inovasi Pelayanan Publik.

Peraturan Pemerintah RI. 2012. Peraturan Pemerintah Republik Indonesia Nomor 79 Tahun 2012 tentang Pelaksanaan UndangUndang Nomor 13 Tahun 2008 tentang Penyelenggaraan Ibadah Haji.

Riyanto. S \& Hatmawan. A. A. 2020. Metode Riset Penelitian Kuantitatif Penelitian Di Bidang Manajemen, Teknik, Pendidikan Dan Eksperimen. Yogyakarta: DeePublish CV Budi Utama.

Sangkala. 2014. Innovative Governance : Konsep dan Aplikasi. Surabaya: Capiya Publishing.

Sumarto dan Hetifa Sj. 2003. Inovasi, Partisipasi dan Good Governance. Bandung: Yayasan Obor Indonesia.

Thijs, N., Hammerschmid, G., \& Palaric, E. 2017. A Comparative Overview of Public Administration Characteristics and Performance in EU28. Brussels: European Commission.

Unaradjan. D. D. 2019. Metode Penelitian Kuantitatif. Jakarta: Grafindo.

Undang-Undang RI. 2009. Undang-Undang Republik Indonesia Nomor 25 Tahun 2009 tentang Pelayanan Publik.

Undang-Undang RI. 2019. Undang-Undang Republik Indonesia Nomor 8 Tahun 2019 tentang Penyelenggaraan Ibadah Haji dan Umrah.

Winarno, B. 2016. Kebijakan Publik Era Globalisasi Cet-1. Yogyakarta: CAPS

\section{Artikel Jurnal}

Afriani, Saiful Bahri, Thanthawi Ishak. 2020. Peran Kantor Kementerian Agama Kabupaten Aceh Utara dalam Melaksanakan Sistem Informasi dan Komputerisasi Haji Terpadu. Asia- Pacific Journal of Public 
Policy, 6(2), 112-125. Tanggal Akses: 15 Mei 2021.

Fahham, A. M. 2015. Penyelenggaraan Ibadah Haji: Masalah dan Penanganannya. Kajian: Menjembatani Teori dan Persoalan Masyarakat dalam Perumusan Kebijakan. Jurnal, 20 (3), 201-218.

Herni Yuliani, Ahmad Sarbini, \& Herman. 2016. Implementasi Sistem Komputerisasi Haji Terpadu (Siskohat) dalam Transparansi Informasi kepada Calon Jemaah Haji. Jurnal Manajemen Dakwah, 1(2), 102-120.

Tanggal Akses: 04 Mei 2021.
Munawaroh, Z., Mudhofi, M., \& Susanto, D. 2017. Efektivitas Sistem Informasi Dan

Komputerisasi Haji Terpadu (Siskohat)

Dalam Penyelenggaraan Ibadah Haji. Jurnal Ilmu Dakwah, 35(2), 225-248. Tanggal Akses: 14 Mei 2021.

Wahyu Syintia Putri, Decky Hendarsyah. 2020. Pengaruh Sistem Pengendalian Internal Terhadap Penerapan Sistem Komputerisasi Haji Terpadu (SISKOHAT). Inovbiz: Jurnal Inovasi Bisnis 8 (2020) 52-58. Tanggal Akses: 04 Mei 2021. 